\title{
Toxoplasma gondii in domestic and wild animals from forest fragments of the municipality of Natal, northeastern Brazil
}

\author{
Toxoplasma gondii em animais domésticos e silvestres de fragmentos florestais do \\ município de Natal, nordeste do Brasil
}

\author{
Gislene Fátima da Silva Rocha Fournier'; Marcos Gomes Lopes²; Arlei Marcili²; Diego Garcia Ramirez²; \\ Igor Cunha Lima Acosta ${ }^{2}$; Juliana Isabel Giuli da Silva Ferreira²; Aline Diniz Cabral²; Júlia Tereza Ribeiro de Lima²; \\ Hilda Fátima de Jesus Pena²; Ricardo Augusto Dias²; Solange Maria Gennari²* \\ ${ }^{1}$ Department of Parasitology, Institute of Biomedical Sciences, University of São Paulo - USP, São Paulo, SP, Brazil \\ ${ }^{2}$ Department of Preventive Veterinary Medicine and Animal Health, Faculty of Veterinary Medicine, University of São Paulo - USP, \\ Sáo Paulo, SP, Brazil
}

Received July 23, 2014

Accepted November 4,2014

\begin{abstract}
Toxoplasmosis stands out as a global disease that has felines as definitive hosts. In the municipality of Natal, Rio Grande do Norte State, Brazil, two parks are notable for their ecological and social importance. This study aimed to investigate the presence of Toxoplasma gondii in short hair cats, bats and small non-volant mammals in these two ecological reserves. Altogether, biological samples were obtained from 154 mammals, 92 wild animals from both areas and 62 domestic cats of the Parque da Cidade. In total, 22 (53.7\%) non-volant wild mammals, 11 (21.5\%) bats and $28(52.8 \%)$ cats were positive for IgG anti-T. gondii antibodies using the Modified Agglutination Test ( $\geq 25)$. It was possible to detect the presence of T. gondii DNA, by means of a molecular amplification of a B1 gene fragment (155bp), in 92 tissue samples from wild animals, including Didelphis albiventris, Monodelphis domestica, Artibeus lituratus, Carollia perspicillata and Glossophaga soricina. Of the 62 cats examined by the same molecular method, T. gondii DNA could be detected in 4 cats. In this study, it was observed the circulation of $T$. gondii in wild species and domestic cats, demonstrating the involvement of wild and domestic animals in the cycle of $T$. gondii.
\end{abstract}

Keywords: Toxoplasma gondii, wild mammals, feral cats, Natal City, Brazil.

\section{Resumo}

Toxoplasmose destaca-se como uma doença global que tem felinos como hospedeiros definitivos. No município de Natal, Rio Grande do Norte, Brasil, dois parques são notáveis por sua importância ecológica e social. Este estudo teve como objetivo investigar a presença de Toxoplasma gondii em gatos de rua, morcegos e pequenos mamíferos não-voadores nestas duas reservas ecológicas. No total, as amostras biológicas foram obtidas de 154 mamíferos, 92 animais selvagens de ambas as áreas e 62 gatos domésticos do Parque da Cidade. No total, 22 (53,7\%) mamíferos silvestres não-voadores, 11 (21,5\%) morcegos e 28 (52,8\%) gatos foram positivos para IgG anti-T. gondii utilizando o Teste de Aglutinação Modificado ( $\geq 25)$. Foi possível detectar a presença de DNA de T. gondii, por meio de uma amplificaçáo molecular de um fragmento do gene B1 (155bp), em 92 amostras de tecido de animais selvagens, incluindo Didelphis albiventris, Monodelphis domestica, Artibeus lituratus, Carollia perspicillata e Glossophaga soricina. Dos 62 gatos examinadas pelo mesmo método molecular, DNA de T. gondii pode ser detectado em quatro gatos. Neste estudo, observou-se a circulaçáo de $T$. gondii em espécies selvagens e gatos domésticos, demonstrando o envolvimento de animais domésticos e selvagens no ciclo de T. gondii.

Palavras-chave: Toxoplasma gondii, mamíferos selvagens, gatos de rua, Cidade de Natal, Brasil.

\footnotetext{
*Corresponding author: Solange Maria Gennari, Department of Preventive Veterinary Medicine and Animal Health, Faculty of Veterinary Medicine, University of São Paulo - USP, Av. Prof. Orlando Marques de Paiva, 87, Cidade Universitária, CEP 05508-270, São Paulo, SP, Brazil, e-mail: sgennari@usp.br
} 


\section{Introduction}

The etiological agent of toxoplasmosis, Toxoplasma gondii, has emerged as one of the most successful parasites. T. gondii is an intracellular protozoan of the Sarcocystidae family of wide prevalence in humans and infect a great diversity of mammals and birds from all regions of the world (DUBEY, 2010; MONTOYA \& LIESENFELD, 2004; REMINGTON et al., 2006).

The exact number of people who carry this parasite around the world is not known, but estimates for European countries show that this figure may represent up to a third of the world population (MONTOYA \& LIESENFELD, 2004). Healthy and infected individuals can become immunocompromised during life and the disease may become important with clinical signs, even causing death (DUBEY, 2008). In this context, strategies focused on prevention against infection with $T$. gondii in urban centers are important and should be considered in the management of public policies.

In Brazil, urban growth has caused the degradation of forested areas for the creation of cities since the colonial period and, in many regions, small islands of vegetation within major urban centers remained preserved, creating a differentiated cycle for $T$. gondii, with the presence of domestic and wild hosts in abundance (DUBEY et al., 2003; LEHMANN et al., 2003; SILVA et al., 2010; VITALIANO et al., 2010). These forest fragments dramatically suffer the effect of unplanned urbanization, including the introduction of domestic species into the wild ecosystem (SALGADO et al., 2007). This intimate relationship leads to the emergence of diseases for several species of animals and humans, as well as causing ecological imbalance due to predation and disappearance of some wild species (DUBEY et al., 2003; LEHMANN et al., 2003; SILVA et al., 2010).

Located in the extreme northeast of Brazil, the state of Rio Grande do Norte occupies an area of 52,796,791 km² with large forested areas. In the capital, Natal, two forest fragments stand out in terms of size and importance. The first, a state park called Parque Estadual das Dunas de Natal, is the largest forest fragment in the municipality, with an area of 1,172 hectares of native forest on dunes, located in the coastal region of the city (FREIRE, 1990; CARVALHO, 2001), and forming an integral part of the Atlantic Rainforest Biosphere Reserve. The second fragment of importance is a municipal park called Parque da Cidade, which is situated within the capital and covers an area of 64 hectares of native forest on dunes, and it contains the last clean aquifer of Natal. However, there have been reports of domestic cats, the main definitive host of $T$. gondii, being abandoned in these two areas in recent years. None of the measures taken by the municipality was effective in reducing the population of these animals, which has been gradually growing.

The aim of this study was to investigate the presence of T. gondii in short hair cats and small wild mammals that live in this region, using serological, molecular and the mouse-bioassay techniques.

\section{Materials and Methods}

\section{Study area}

Two forest fragments were selected - Parque Estadual das Dunas de Natal and Parque da Cidade - both located in the Atlantic Rainforest Biome. The Parque das Dunas (5 $49^{\circ} 41^{\prime \prime} \mathrm{S}$ and $\left.35^{\circ} 11^{\prime} 25^{\prime \prime} \mathrm{W}\right)$ covers 1,172 hectares of forest and is characterized by the predominance of species peculiar to Coastal Tablelands, Atlantic Forest and also Caatinga (FREIRE, 1990). The Parque da Cidade (5'50'45"S and 35'14'0"W) covers approximately 64 acres and features more undergrowth with vegetation types typical of Caatinga (RAMALHO \& PIMENTA, 2010).

\section{Collection of biological samples and sterilization of cats}

A seven-day campaign was conducted in February 2013 to capture short hair cats and collect biological samples. The animals were captured manually and underwent surgical sterilization after clinical evaluation. These cats were divided into two age groups: young (animals with primary dentition) and adult (animals with permanent dentition). The male reproductive organs were stored in $100 \%$ ethanol and those of the females were kept at a temperature of $4^{\circ} \mathrm{C}$ and sent to the Department of Preventive Veterinary Medicine and Animal Health (VPS) of the Faculty of Veterinary Medicine, USP, São Paulo, SP, for mouse bioassay and molecular tests. Cats that died during the collection period or were found dead in the park areas had their tissues (heart, brain, intestine, liver, spleen, lung, tongue, testis, uterus and fetus) removed and also sent for molecular testing and bioassay. At the end, the cats that underwent sterilization surgery were identified and passed on for adoption or released at the same place of capture.

\section{Capture of small terrestrial and flying mammals}

Two field campaigns for the capture of wild animals were conducted: one during the dry season (October 2012) and the other during the rainy season (February 2013). The animals selected for this study included groups of small wild mammals and bats. When necessary, the wild animals caught were anesthetized (xylazine, mean dose $5 \mathrm{mg} / \mathrm{kg}$ and ketamine, mean dose $50 \mathrm{mg} / \mathrm{kg}$ ) for the collection of blood, which was done by cardiac puncture from the tail vein or the cephalic vein. Three animals of each species were euthanized, and then fragments of the lungs, kidneys, spleen, liver, heart, tongue and brain were collected for molecular analyses and bioassays in mice. The skins of the euthanized wild animals were given to the Museum of Natural History at the Pontifical Catholic University of Minas Gerais after identification of the species.

The licenses for catching wild animals and the euthanasia of three specimens per species were granted by the Biodiversity Authorization and Information System (SISBio), under number 32104-2, of the Institute of Sustainable Development and the Environment of Rio Grande do Norte (IDEMA-RN) and by the Ethics Committee on Animal Use of the Institute of Biomedical Sciences, USP, protocol number 204. 


\section{Investigation of IgG anti-T. gondii antibodies}

The sera obtained were examined by the modified agglutination test - MAT (DESMONTS \& REMINGTON, 1980; DUBEY \& DESMONTS, 1987). Animals with titers greater than or equal to 25 were considered positive (FORNAZARI et al., 2009; SILVA et al., 2001). Positive samples were diluted in base 2 to obtain the final titer. In all reactions, previously known positive and negative controls and antigen controls were used.

\section{Molecular tests}

DNA extraction from tissues was performed according to the protocol established by Kit Wizard SV Genomic DNA Purification (Promega, Fitchburg, Wisconsin, USA). The samples were tested by a nested PCR ( $n$ PCR) for the B1 gene (BURG et al., 1989). For the first round of PCR amplification, $10 \mu \mathrm{M}$ of external primers T1 (5'-AGCGTCTCTCTTCAAGCAGCGTA-3') and T2 (5'-TCCGCAGCGACTTCTATCTCTGT-3') were used, and $10 \mu \mathrm{M}$ of internal primers $\mathrm{T} 3$ (5'-TGGGAATGAAAGAGACGCTAAT GTG-3') and T4 (5'-TTAAAGCGTTCGTGGTCAACTATCG-3') were used for the $n$ PCR reaction (155bp) using the protocol described by Yai et al. (2003). In this reaction, $14.1 \mu \mathrm{L}$ of ultrapure water were used for each sample, with $2.5 \mu \mathrm{L}$ of reaction buffer $(50$ $\mathrm{mM} \mathrm{KCl}, 10 \mathrm{mM}$ Tris- $\mathrm{HCl}, \mathrm{pH} 9.0), 4.0 \mu \mathrm{L}$ of dNTP mixture - dATP, dTTP, dCTP and dGTP $(1.25 \mathrm{mM}), 1.25 \mathrm{ml}$ of each primer $(10 \mu \mathrm{M}), 0.75 \mu \mathrm{L} \mathrm{MgCl}_{2}(50 \mathrm{mM}), 0.15 \mu \mathrm{L}$ of Taq DNA polymerase $(5 \mathrm{U} / \mu \mathrm{L})$ Platinum ' (Invitrogen, Carlsbad, CA, USA) and $1.0 \mu \mathrm{L}$ of extracted DNA sample. The same quantities of the reagent mixture were used with the addition of $1.0 \mu \mathrm{L}$ of the product amplified in the PCR were used for the $n$ PCR. PCR was performed with 25 cycles at $94^{\circ} \mathrm{C}$ for 45 seconds, $55^{\circ} \mathrm{C}$ for 1 minute and $72^{\circ} \mathrm{C}$ for 1.5 minutes, and $n$ PCR was performed with 35 cycles at $94^{\circ} \mathrm{C}$ for 45 seconds, $55^{\circ} \mathrm{C}$ for 1 minute and $72^{\circ} \mathrm{C}$ for 1.5 minutes. The reactions were preceded by an initial denaturation step at $94^{\circ} \mathrm{C}$ for 3 minutes and a final extension at $72^{\circ} \mathrm{C}$ for 10 minutes. All reactions were developed on $2.0 \%$ agarose gel stained with SYBR Safe (Molecular Probes, Portland, Oregon, USA) and viewed under UV light.

\section{Bioassay in mice}

Specimens of Didelphimorphia, Rodentia and Chiroptera were euthanized for bioassay in mice. The uteri of the domestic cats that underwent sterilization surgery were also used in the bioassay. Each bioassay was conducted for only one animal, giving a total of 116 bioassays. Samples were processed according to a previously described protocol (DUBEY, 1998). Briefly, the tissues of animals were homogenized in a mortar and pestle with 5 volumes $(w / v)$ of aqueous $0.85 \% \mathrm{NaCl}$ (saline). This tissue homogenate was mixed with 5 volumes of acidic pepsin, the mixture was incubated for $1 \mathrm{~h}$ at $37^{\circ} \mathrm{C}$, centrifuged, neutralized with sodium bicarbonate, and mixed with antibiotics. Subsequently, $1 \mathrm{~mL}$ of the homogenate was subcutaneously inoculated into each of three Swiss albino female mice from the colony of the FMVZ-USP, São Paulo, SP,
Brazil. Before adding the acidic pepsin, one aliquot of $1 \mathrm{~mL}$ of homogenate tissue (primary sample) from each animal was stored at $-70^{\circ} \mathrm{C}$ until the extraction of genomic DNA.

The inoculated mice were examined for $T$. gondii infection as previously described (DUBEY, 2010). Impression smears of the lung and cerebrum samples of the mice that died were microscopically examined for $T$. gondii organisms. The survivors were bled nine weeks post-inoculation (p.i.), and serum from each mouse was tested for antibodies to T. gondii $(\geq 25)$ using the modified agglutination test (MAT). All survivors were euthanized (T61 Intervet, Campinas, SP, Brazil) nine weeks p.i. and their brains were microscopically examined for tissue cysts. T. gondii was considered to have been isolated when stages of the parasite (tachyzoites and/or cysts) were found in mouse tissues. Samples of hearts and brains of all mice were referred for molecular tests.

\section{Statistical analysis of data}

Possible associations between the occurrence values of anti-T. gondii antibodies in non-volant wild mammals caught in each park were analyzed using the Pearson chi-squared test. The same associations were analyzed for the animals that were positive by molecular diagnosis using Fisher's exact test. Regarding the bats, due to the fact that these animals frequented both parks, the occurrence of anti-T. gondii was determined using the bats captured in both parks, with no comparison being made between capture sites.

For cats that were captured only in the Parque da Cidade, associations between age and sex and the presence of anti-T. gondii were evaluated using Pearson's chi-squared test. EPI-INFO 6 software (CDC, Atlanta, Georgia, USA) was used for all analyses. Differences were considered statistically significant at $\mathrm{p} \leq 0.05$.

\section{Results}

\section{Captured animals}

Among the wild animals captured, 18 species of wild mammals were identified, of which three belong to the order Rodentia, eight to the Chiroptera order, four to the Didelphimorphia order, one species belonging to the Cingulata order, one species of the Primates order and one species of the Carnivora order. In the Parque da Cidade and Parque das Dunas, specimens were captured of 10 and 12 species, respectively (Table 1).

Altogether, biological samples were obtained from 154 mammals, of which 92 were wild animals and 62 were domestic cats, the latter being from the Parque da Cidade. Of the wild mammals, 51 specimens (59.8\%) were species of the order Chiroptera, flying animals that are able to travel over large areas and, therefore, are not necessarily always present in the same park. Of the small non-volant mammals, 23 (56.1\%) were from the Parque da Cidade and 18 (43.9\%) from the Parque das Dunas. 
Table 1. Order, species and number of captured and sampled wild mammals in the conservation areas (Parque da Cidade and Parque das Dunas) in Natal, Rio Grande do Norte, Brazil (2012 and 2013).

\begin{tabular}{|c|c|c|c|c|c|}
\hline \multirow[t]{2}{*}{ Order } & \multirow[t]{2}{*}{ Species } & \multirow[t]{2}{*}{ Common Name } & \multicolumn{3}{|c|}{ Number of Specimens } \\
\hline & & & $\begin{array}{c}\text { Parque da } \\
\text { Cidade }\end{array}$ & $\begin{array}{c}\text { Parque das } \\
\text { Dunas } \\
\end{array}$ & Total \\
\hline \multirow[t]{3}{*}{ Rodentia } & Necromys lasiurus & hairy-tailed bolo & 20 & 0 & 2 \\
\hline & Thrichomys apereoides & mouse & 0 & 1 & 1 \\
\hline & Rattus rattus & spiny rat black rat & & 1 & 1 \\
\hline \multirow[t]{8}{*}{ Chiroptera } & Artibeus lituratus & neotropical fruit bat & 1 & 15 & 16 \\
\hline & Myotis nigricans & neotropical fruit bat & 0 & 14 & 14 \\
\hline & Uroderma bilobatum & neotropical fruit bat & 1 & 7 & 8 \\
\hline & Sturnira lilium & neotropical fruit bat & 1 & 0 & 1 \\
\hline & Carollia perspicillata & short-tailed fruit bats & 6 & 1 & 7 \\
\hline & Lichonycteris degener & neotropical fruit bat & 2 & 0 & 2 \\
\hline & Glossophaga soricina & pallas's long-tongued bat & 0 & 2 & 2 \\
\hline & Centronycteris maximiliani & shaggy Bat & 0 & 1 & 1 \\
\hline Carnivora & Lycalopex vetulus & hoary fox & 1 & 0 & 1 \\
\hline Cingulata & Euphractus sexcinctus & six-banded armadillo & 2 & 0 & 2 \\
\hline \multirow[t]{4}{*}{ Didelphimorphia } & Didelphis albiventris & white-eared opossum & 14 & 11 & 25 \\
\hline & Monodelphis domestica & gray short-tailed opossum & 4 & 0 & 4 \\
\hline & Caluromys philander & bare-tailed woolly opossum & 0 & 1 & 1 \\
\hline & Cryptonanus agricolai & agricola's gracile opossum & 0 & 1 & 1 \\
\hline Primates & Callithrix jacchus & common marmoset & 0 & 3 & 3 \\
\hline Total & & & 34 & 58 & 92 \\
\hline
\end{tabular}

\section{Investigation of anti-T. gondii antibodies in wild animals}

From the 92 animals caught, 74 serum samples from 16 species were obtained. Among the non-volant mammals, no association was observed when comparing the occurrences of positive animals in each of the forest fragments $(p=0.11)$. In the Parque da Cidade, 14 (66.7\%) non-volant wild mammals had anti-T. gondii antibodies and in the Parque das Dunas 8 (61.5\%) of these mammals were positive. Regarding bats, $11(21.5 \%)$ of the 40 serum samples had anti- $T$. gondii. The titers of anti- $T$. gondii antibodies ranged from 25 to 3.200 .

\section{Investigation of anti-T. gondii antibodies in domestic} cats

Regarding cats, 53 serum samples were obtained. Of these, 28 (52.8\%) were seropositive for T. gondii. During the two field campaigns, the number of cats observed and counted in the Parque das Dunas did not exceed 20 animals and these were not captured due to the feral habits. In the Parque da Cidade, the number of cats counted in the two campaigns exceeded 150 animals. Of the young and adult cats, $48.9 \%(22 / 45)$ and $62.5 \%$ $(5 / 8)$ were seropositive, respectively. There was no statistical difference between the proportions of seropositive animals and age $(p=0.55)$. Regarding gender, $50 \%(15 / 30)$ of females and $54.5 \%$ $(12 / 22)$ of males were positive, and there was no association between sex and the presence of anti- $T$. gondii antibodies $(\mathrm{p}=0.79)$. The titers of anti- $T$. gondii antibodies ranged from 25 to 12,800 , with 13 cats having a titer of 25 , three having 50 , six having 100 , one having 200 , two having 400 , one having 1,600 , one having 6,400, and one cat had a titer of 12,800 .

\section{Molecular investigation of T. gondii}

The PCR for amplification of the B1 gene was done on DNA extracted from 680 samples obtained both from wild animals and from cats. Of the 92 wild animals captured, 69 were necropsy (483 tissue samples) and 74 had blood collected, totaling 557 samples. The remaining 123 samples were obtained from tissues of cats undergoing sterilization (testis, uterus and blood) and animals that died during the sampling period (eight samples from three cats) and/or animals that only had their blood collected (53 animals).

All wild animals caught were tested in at least one type of sample (tissue or blood). Of the wild animals tested, 15 $(16.3 \%)$ were positive in at least one tissue or blood analysis (Table 2). T. gondii DNA was detected in 16.3\% (15/92) of 92 animals analyzed, of which $21.6 \%(11 / 51)$ were bats and $12.9 \%(4 / 31)$ marsupials. There was no association between the number of positive non-volant wild mammals for the presence of T. gondii DNA and the forest fragment of origin $(\mathrm{p}=1.00)$ according to Fisher's exact test. Eight bats that were positive in the molecular test showed no positive serology for T. gondii (MAT $\leq 25)$.

T. gondii DNA was detected in five of the $62(8.1 \%)$ cats that had blood or tissues analyzed (Table 3, Figure 1 ). There was no association between the sex $(\mathrm{p}=0.14)$ and age $(\mathrm{p}=0.70)$ of the cats and the molecular detection of T. gondii in tissues. 
Table 2. Identification of positive animals from each park in the molecular test for the presence of $T$. gondii with the B1 gene using different tissues and blood related to the serology results (MAT $\geq 25$ ).

\begin{tabular}{|c|c|c|c|c|c|c|c|c|c|c|c|}
\hline \multirow{2}{*}{ Code } & \multirow{2}{*}{ Species } & \multirow{2}{*}{ Location } & \multicolumn{8}{|c|}{ Organs Examined for B1 } & \multirow{2}{*}{ MAT } \\
\hline & & & $\mathrm{He}$ & $\mathrm{Br}$ & To & Sp & $\mathbf{L i}$ & $\mathbf{K i}$ & $\mathbf{L u}$ & Bl & \\
\hline $24 S$ & Artibeus lituratus (great fruit-eating bat) & Parque da Cidade & $\mathrm{N}$ & $\mathrm{N}$ & $\mathrm{N}$ & $\mathrm{P}$ & $\mathrm{P}$ & $\mathrm{N}$ & $\mathrm{N}$ & $\mathrm{N}$ & $<25$ \\
\hline $46 S$ & Artibeus lituratus (great fruit-eating bat) & Parque das Dunas & $\mathrm{P}$ & $\mathrm{P}$ & $\mathrm{N}$ & $\mathrm{P}$ & $\mathrm{P}$ & $\mathrm{P}$ & $\mathrm{P}$ & $\mathrm{N}$ & $<25$ \\
\hline $42 S$ & Artibeus lituratus (great fruit-eating bat) & Parque das Dunas & $\mathrm{P}$ & $\mathrm{P}$ & $\mathrm{P}$ & $\mathrm{N}$ & $\mathrm{N}$ & $\mathrm{N}$ & $\mathrm{N}$ & $\mathrm{N}$ & 25 \\
\hline $74 S$ & Artibeus lituratus (great fruit-eating bat) & Parque das Dunas & $\mathrm{P}$ & $\mathrm{P}$ & $\mathrm{N}$ & $\mathrm{N}$ & $\mathrm{N}$ & $\mathrm{N}$ & $\mathrm{N}$ & $\mathrm{N}$ & $<25$ \\
\hline $73 S$ & Artibeus lituratus (great fruit-eating bat) & Parque das Dunas & $\mathrm{N}$ & $\mathrm{P}$ & $\mathrm{N}$ & $\mathrm{P}$ & $\mathrm{P}$ & $\mathrm{N}$ & $\mathrm{P}$ & $\mathrm{N}$ & $<25$ \\
\hline $97 \mathrm{~S}$ & Artibeus lituratus (great fruit-eating bat) & Parque das Dunas & $\mathrm{N}$ & $\mathrm{N}$ & $\mathrm{N}$ & $\mathrm{P}$ & $\mathrm{N}$ & $\mathrm{N}$ & $\mathrm{N}$ & $\mathrm{N}$ & $<25$ \\
\hline $98 \mathrm{~S}$ & Artibeus lituratus (great fruit-eating bat) & Parque das Dunas & $\mathrm{P}$ & $\mathrm{N}$ & $\mathrm{N}$ & $\mathrm{N}$ & $\mathrm{N}$ & $\mathrm{N}$ & $\mathrm{N}$ & $\mathrm{N}$ & $<25$ \\
\hline $99 \mathrm{~S}$ & Artibeus lituratus (great fruit-eating bat) & Parque das Dunas & $\mathrm{N}$ & $\mathrm{P}$ & $\mathrm{N}$ & $\mathrm{N}$ & $\mathrm{N}$ & $\mathrm{N}$ & $\mathrm{N}$ & $\mathrm{N}$ & $<25$ \\
\hline $16 S$ & Carollia perspicillata (Seba's short-tailed bat) & Parque da Cidade & $\mathrm{P}$ & $\mathrm{N}$ & $\mathrm{N}$ & $\mathrm{N}$ & $\mathrm{N}$ & $\mathrm{N}$ & $\mathrm{N}$ & $\mathrm{N}$ & 25 \\
\hline $17 \mathrm{~S}$ & Carollia perspicillata (Seba's short-tailed bat) & Parque da Cidade & $\mathrm{P}$ & $\mathrm{N}$ & $\mathrm{N}$ & $\mathrm{N}$ & $\mathrm{N}$ & $\mathrm{N}$ & $\mathrm{N}$ & $\mathrm{N}$ & 50 \\
\hline $40 S$ & Glossophaga soricina (Pallas's long-tongued bat) & Parque das Dunas & $\mathrm{N}$ & $\mathrm{N}$ & $\mathrm{N}$ & $\mathrm{N}$ & $\mathrm{N}$ & $\mathrm{N}$ & $\mathrm{N}$ & $\mathrm{P}$ & $<25$ \\
\hline $28 \mathrm{~S}$ & Didelphis albiventris (white-eared opossum) & Parque da Cidade & $\mathrm{N}$ & $\mathrm{P}$ & $\mathrm{N}$ & $\mathrm{P}$ & $\mathrm{N}$ & $\mathrm{P}$ & $\mathrm{N}$ & $\mathrm{N}$ & 3200 \\
\hline $48 \mathrm{~S}$ & Didelphis albiventris (white-eared opossum) & Parque das Dunas & $\mathrm{P}$ & $\mathrm{P}$ & $\mathrm{N}$ & $\mathrm{N}$ & $\mathrm{N}$ & $\mathrm{N}$ & $\mathrm{N}$ & $\mathrm{N}$ & 25 \\
\hline $68 \mathrm{~S}$ & Didelphis albiventris (white-eared opossum) & Parque das Dunas & $\mathrm{N}$ & $\mathrm{N}$ & $\mathrm{N}$ & $\mathrm{P}$ & $\mathrm{N}$ & $\mathrm{N}$ & $\mathrm{N}$ & $\mathrm{N}$ & 25 \\
\hline $25 S$ & Monodelphis domestica (gray short-tailed opossum) & Parque da Cidade & $\mathrm{N}$ & $\mathrm{P}$ & $\mathrm{N}$ & $\mathrm{N}$ & $\mathrm{N}$ & $\mathrm{N}$ & $\mathrm{N}$ & $\mathrm{N}$ & 50 \\
\hline \multicolumn{3}{|c|}{ Total positives } & 7 & 8 & 1 & 6 & 3 & 2 & 2 & 1 & 7 \\
\hline
\end{tabular}

$\mathrm{N}=$ Negative; $\mathrm{P}=$ Positive; $\mathrm{He}=$ heart $\mathrm{Br}=$ brain; $\mathrm{To}=$ tongue; $\mathrm{Sp}=$ spleen; $\mathrm{Li}=$ liver; $\mathrm{Ki}=$ kidney; $\mathrm{Lu}=$ lung; $\mathrm{Bl}=$ blood; MAT = modified agglutination test.

Table 3. Results of $n$ PCR (B1 gene) for DNA samples positive for T. gondii obtained from the tissues and blood of domestic cats from the Parque da Cidade and the relation with the serology results (MAT $\geq 25$ ), Natal, Rio Grande do Norte, Brazil, 2013.

\begin{tabular}{|c|c|c|c|c|c|c|c|c|c|c|}
\hline \multirow{2}{*}{ Code } & \multirow{2}{*}{ Age } & \multirow{2}{*}{ Sex } & \multicolumn{7}{|c|}{ Tissue positive in B1 } & \multirow{2}{*}{ MAT } \\
\hline & & & $\mathrm{He}$ & $\mathrm{Br}$ & To & Ut & Te & Bl & $\mathrm{Fe}$ & \\
\hline G69 & Adult & Female & $\mathrm{P}$ & $\mathrm{P}$ & $\mathrm{N}$ & $\mathrm{P}$ & - & $\mathrm{N}$ & $\mathrm{P}$ & 12.800 \\
\hline G213 & Young & Male & - & - & - & - & $\mathrm{P}$ & $\mathrm{N}$ & - & 25 \\
\hline G27 & Adult & Female & - & - & - & $\mathrm{N}$ & - & $\mathrm{P}$ & - & 100 \\
\hline G110 & Young & Female & - & - & - & $\mathrm{N}$ & - & $\mathrm{P}$ & - & 100 \\
\hline G107 & Young & Female & $\mathrm{N}$ & $\mathrm{P}$ & $\mathrm{N}$ & $\mathrm{N}$ & - & - & - & - \\
\hline Total & & & 1 & 2 & 0 & 1 & 1 & 2 & 1 & 4 \\
\hline
\end{tabular}

$\mathrm{N}=$ Negative; $\mathrm{P}$ = Positive; $\mathrm{He}$ = heart $\mathrm{Br}$ = brain; $\mathrm{To}=$ tongue; $\mathrm{Ut}=$ uterus; $\mathrm{Te}=$ testicle; $\mathrm{Bl}=$ blood; $\mathrm{Fe}=$ fetus; $\mathrm{MAT}=$ modified agglutination test .

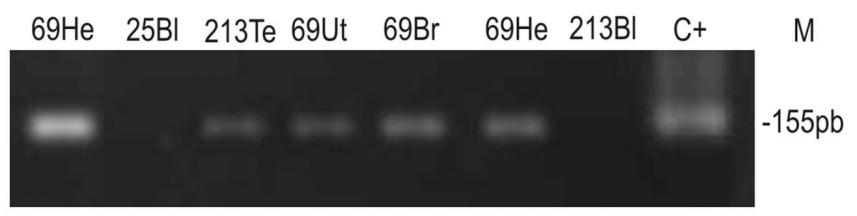

Figure1. Nested PCR ( $n$ PCR) amplified DNA fragments corresponding to $\mathrm{B} 1$ gene. Toxoplasma gondii from the $\mathrm{RH}$ strain of T. gondii isolated were used as controls. Agarose gels (2.0\%) stained with ethidium bromide. $\mathrm{N}=$ Negative; $\mathrm{P}=$ Positive; $\mathrm{He}=$ heart; $\mathrm{Br}=$ brain; $\mathrm{To}=$ tongue; $\mathrm{Ut}=$ uterus; $\mathrm{Te}=$ testicle; $\mathrm{Bl}=$ blood; $\mathrm{Fe}=$ fetus.

\section{Bioassay in mice}

Using the samples obtained in the field, 116 bioassays were conducted in mice, two of these with water samples obtained from each of the parks, 69 with wildlife animal tissues (brain, heart and tongue) and 45 with tissues from domestic cats. From the felines, 37 bioassays used tissue from the uteri of sterilized cats, 3 used a pool of brain, heart and tongue from animals that died during the sampling period, 3 were performed with pooled samples of intestinal contents, obtained from the same cats that had died, and 2 samples of fetuses from 2 pregnant cats that underwent sterilization. No isolate of $T$. gondii was obtained by mouse bioassay.

\section{Discussion}

The results of this study demonstrate that, in the parks studied, T. gondii has a well-established population in a wide variety of hosts. Anti-T. gondii antibodies (MAT $\geq 25$ ) were found in 34 (45.9\%) of the 74 wild animals captured, representing 16 of the 18 species collected. Comparison with other studies is difficult, since the samples were collected from wild animals of different species that have different habits from each other and are not often targets of research into T. gondii. Siqueira et al. (2013) identified anti- $T$. gondii antibodies (MAT $\geq 25)$ in various species of rodents and marsupials in areas of the city of Recife, northeastern Brazil. In these animals, 6.7\% (15/223) of the marsupials and $5.7 \%(10 / 174)$ of the rodents had anti-T. gondii 
antibodies. In the present study, with the same serological test and cutoff point, 76\% (19/25) of marsupials were seropositive for $T$. gondii, demonstrating a greater prevalence of infected animals when compared to other forested areas of the same region. These results indicate a possible interference caused by the presence of the large number of domestic cats in the study areas and reinforces the need for the intervention of governmental agencies for the implementation of plans of action to control the cat population in the parks and in the city, and campaigns clarifying the need for such control to the local population.

Among the species captured in the two forest fragments, Didelphis albiventris stands out for having high occurrence values for anti-T. gondii antibodies $(77.8 \%$ in the Parque da Cidade and $76.9 \%$ in the Parque das Dunas). D. albiventris is commonly found in the study area and is not at risk of extinction, being seen as an opportunistic species in anthropogenic environments and, when in high densities, these have been described as bioindicators of degraded forest areas (PAGLIA et al., 2012).

Comparing the two forest fragments studied in relation to the data obtained for the epidemiology of $T$. gondii, it can be concluded that the Parque da Cidade presents a more serious situation with regard to the ecological balance and increasing population of $T$. gondii. The Parque da Cidade is within the central area of the city and demonstrates a range of ecological consequences for the ecosystem that can alter the reproductive cycles of several host species, climate characteristics at the edges of forests and water quality. Moreover, it was observed that the domestic cat is part of the ecological chain as a predator and that the large population of cats may be influencing the diversity of native wildlife. The tightening of the relationship between domestic and wild animals, in addition to causing increased competition for wild and anthropogenic habitats, can result in the transmission of diseases from one group to the other (OGRZEWALSKA et al., 2011).

In the present study, there was little information on the number of domestic cats in the two areas studied. In 2012, the administration of Natal estimated 150 cats concentrated at four points separated from one another by 400 meters (personal communication) within the Parque da Cidade. These points are locations where there are points for collecting the water from the water table that supplies the city. No census has been performed to estimate the number of cats in the Parque das Dunas, however, during the second field campaign of this study, only 20 animals were counted. This number, even if it is not backed by scientific methodology, demonstrates that there is a distinct difference in the populations of cats present in each park studied. The low number of cats observed in the Parque das Dunas can also be explained by the large size of this forest fragment, allowing cats to frequent the internal areas of the park. In this area, it was observed that cats form small groups inside the forest, and do not allow human approach, being practically feral.

The high occurrence of anti-T. gondii antibodies in cats that live in the Parque da Cidade (51.9\%) presents an alarming situation for public health, since the positive serology indicates that these cats have already excreted $T$. gondii oocysts in the environment, and reinforces the significance of these animals in the epidemiology of the parasite. There are no studies of seroprevalence in cats in the state of Rio Grande do Norte. Some already published data show marked differences between the occurrences obtained in this study and in studies done elsewhere. Pena et al. (2006) examined feral cats from several municipalities in the state of São Paulo and found 23.4\%. Silva et al. (2002) found a prevalence of $26.7 \%$ for feral cats from São Paulo and Guarulhos. These studies used the same test and the same cutoff point as those used in the current study (MAT $\geq 25$ ).

In Santa Isabel do Ivaí, in the state of Paraná, southern Brazil, $84.4 \%$ of cats were positive by MAT ( $\geq 25$ ) (DUBEY et al., 2004). Although listed here, comparisons of occurrence values must be analyzed with care due to differences in the sampling and techniques used in different studies. It is known that each naturally infected cat can, in a few days, excrete more than 500 million oocysts into the environment after infection (DUBEY, 2010). Taking this value into account, in the Parque da Cidade alone, it can be estimated that the positive animals found there may have been responsible for the excretion of approximately 14 billion oocysts over a period of their lives, and this park is where water is captured for the municipality. Although this water is underground and relatively deep, this fact deserves the attention of the local authorities.

In the present study, the number of positive domestic cats in molecular diagnosis was low $(8.1 \%)$ when compared to the serology results $(52.8 \%)$. This could be explained by the fact that the research was conducted in selected tissues, such as brain and skeletal and cardiac muscle, in only two of the 62 cats evaluated. The cats were not euthanized and most of the tissue used came from the sterilization of these animals and from blood. However, the results showed that organ tissues of the reproductive tract of cats (testis and uterus) can also harbor $T$. gondii. The reproductive organs, although not organs of choice for diagnosis, can be more easily obtained and used for this purpose. The blood used for investigating the DNA of the parasite only presents circulating T. gondii during the acute phase of the disease (PENA et al., 2006), which makes its use somewhat unsuitable for molecular diagnosis in chronic cases of infection. Even so, of the 53 blood samples tested by the molecular method, two were positive and, in these, the titers of anti-T. gondii antibodies were 100 .

The molecular diagnosis of $T$. gondii used in this study is quite widespread in studies with this coccidian. The B1 gene is considered to be highly specific for this parasite due to its multiple repeats in the DNA (BURG et al., 1989; KAUFMANN et al., 1996; SCHATZBERG et al., 2003; TERRA et al., 2004). The proportion of positive wild animals in molecular testing (15/92 or $16.3 \%$ ) was also lower than that for serology (45.9\%), as was observed for the cats. Of all the tissues examined for detection of the T. gondii DNA using the B1 gene, samples from the brain, heart and spleen were the most frequently positive with eight, seven and six positive samples, respectively. With the exception of the spleen, the others have been the organs of choice for the diagnosis of $T$. gondii infection in most studies with domestic species (DUBEY et al., 2012).

The low molecular occurrence of the parasite in the wild animals assessed may be due to low parasite load in the organs analyzed, especially in bats, for which the biology of T. gondii is little known. There are no data on the physiology of these 
mammals showing the time required for the animal to produce antibodies against $T$. gondii after infection and for how long these antibodies can be found in the circulation. As such, there is as yet no validation of a serological test for the diagnosis of toxoplasmosis in bats.

For a better understanding of the role of bats in the toxoplasmosis cycle, it would be important to conduct experimental studies of infection, which would provide information on the antibody titers, their onset and duration of persistence in the circulation, and information on the pathogenicity of this coccidium in different bat species. There is a recent report of clinical toxoplasmosis in two captive megachiropteran frugivorous bats (Pteropus conspicillatus and Pteropus scapulatus) from Australia by Sangster et al. (2012). Also recently, Cabral et al. (2013) reported the first isolation and genotyping of $T$. gondii from two Brazilian bats, the Desmodus rotundus vampire bat and the Molossus molossus insectivorous bat from São Paulo city.

In the epidemiological chain of $T$. gondii, both in urban environments and in wild environments, carnivorism is the main route of transmission of the parasite to the feline (DUBEY et al., 2010). In the wild environment, small mammals are considered staples in the diet of several species of wild felines and, possibly, the domestic cat (CAÑÓN-FRANCO et al., 2013). Some studies have shown that the rate of $T$. gondii infection in these felines is related to the predator-prey relationship, and therefore dependent on the availability of food for species considered to be prey (AFONSO et al., 2007). In the Parque da Cidade, there are no top-level predators, such as wild cats, so the population of domestic cats grows without interspecific competition. In contrast, the Parque das Dunas provides areas of dense forest capable of harboring predator species, including small and medium-sized neotropical felines, making the propagation of domestic cats inside this forest fragment difficult.

The observations in this study show evidence of a region greatly affected by the proximity of humans and their domestic animals, and indicate that they are interfering with the health of wild animals. Since both parks are frequented by humans, measures for controlling the population of cats and environmental conservation measures should be implemented in view of the importance of $T$. gondii for animal health and public health.

\section{Acknowledgements}

We thank FAPESP, São Paulo, Brazil, for the financial support. SMG and HFJP are in receipt of a fellowship from CNPq, Brazil.

\section{References}

Afonso E, Poulle ML, Lemoine M, Villena I, Aubert D, Gilot-Fromont E. Prevalence of Toxoplasma gondii in small mammals from the Ardennes region, France. Folia Parasitol (Praha) 2007; 54(4): 313-314. http:// dx.doi.org/10.14411/fp.2007.041. PMid:18303774

Burg JL, Grover CM, Pouletty P, Boothroyd JC. Direct and sensitive detection of a pathogenic protozoan, Toxoplasma gondii, by polymerase chain reaction. J Clin Microbiol 1989; 27(8): 1787-1792. PMid:2768467.
Cabral AD, Gama AR, Sodré MM, Savani ESMM, Galvão-Dias MA, Jordão LR, et al. First isolation and genotyping of Toxoplasma gondii from bats (Mammalia: Chiroptera). Vet Parasitol 2013; 193(1-3): 100104. http://dx.doi.org/10.1016/j.vetpar.2012.11.015. PMid:23200751

Cañón-Franco WA, De Araújo FAP, Gennari SM. Toxoplasma gondii in small neotropical wild felids. BrazJ Vet Res Anim Sci 2013; 50(1): 55-67.

Carvalho MM. Clima Urbano e Vegetação: Estudo Analitico e Prospectivo do Parque das Dunas em Natal [Dissertação]. Natal: Universidade Federal do Rio Grande do Norte; 2001.

Desmonts G, Remington JS. Direct agglutination test for diagnosis of Toxoplasma infection: method for increasing sensitivity and specificity. J Clin Microbiol 1980; 11(6): 562-568. PMid:7000807.

Dubey JP. Refinement of pepsin digestion method for isolation of Toxoplasma gondii from infected tissues. Vet Parasitol 1998; 74(1): 75-77. http://dx.doi.org/10.1016/S0304-4017(97)00135-0. PMid:9493311

Dubey JP. Toxoplasmosis of animals and humans. 2nd ed. Boca Raton: CRC Press; 2010.

Dubey JP. The history of Toxoplasma gondii-the first 100 years. J Eukaryot Microbiol 2008; 55(6): 467-475. http://dx.doi.org/10.1111/ j.1550-7408.2008.00345.x. PMid:19120791

Dubey JP, Desmonts G. Serological responses of equids fed Toxoplasma gondii oocysts. Equine Vet J 1987; 19(4): 337-339. http://dx.doi. org/10.1111/j.2042-3306.1987.tb01426.x. PMid:3622463

Dubey JP, Lago EG, Gennari SM, Su C, Jones JL. Toxoplasmosis in humans and animals in Brazil: high prevalence, high burden of disease, and epidemiology. Parasitology 2012; 139(11): 1375-1424. http://dx.doi. org/10.1017/S0031182012000765. PMid:22776427

Dubey JP, Navarro IT, Sreekumar C, Dahl E, Freire RL, Kawabata $\mathrm{HH}$, et al. Toxoplasma gondii infections in cats from Paraná, Brazil: seroprevalence, tissue distribution, and biologic and genetic characterization of isolates. J Parasitol 2004; 90(4): 721-726. http:// dx.doi.org/10.1645/GE-382R. PMid:15359466

Dubey JP, Zarnke R, Thomas NJ, Wong SK, Van Bonn W, Briggs $\mathrm{M}$, et al. Toxoplasma gondii, Neospora caninum, Sarcocystis neurona, and Sarcocystis canis-like infections in marine mammals. Vet Parasitol 2003; 116(4): 275-296. http://dx.doi.org/10.1016/S0304-4017(03)00263-2. PMid: 14580799

Dubey JP, Rajendran C, Ferreira LR, Kwok OCH, Sinnett D, Majumdar $\mathrm{D}$, et al. A new atypical highly mouse virulent Toxoplasma gondii genotype isolated from a wild black bear in Alaska. J Parasitol 2010; 96(4): 713-716. http://dx.doi.org/10.1645/GE-2429.1. PMid:20486739

Fornazari F, Langoni H, da Silva RC, Guazzelli A, Ribeiro MG, Chiacchio SB. Toxoplasma gondii infection in wild boars (Sus scrofa) bred in Brazil. Vet Parasitol 2009; 164(2-4): 333-334. http://dx.doi.org/10.1016/j. vetpar.2009.05.005. PMid:19515494

Freire MSB. Levantamento florístico do Parque Estadual das Dunas de Natal. Acta Bot Bras 1990; 4(2): 41-59.

Kaufmann H, Yamage M, Roditi I, Dobbelaere D, Dubey JP, Holmdahl OJ, et al. Discrimination of Neospora caninum from Toxoplasma gondii and other apicomplexan parasites by hybridization and PCR. Mol Cell Probes 1996; 10(4): 289-297. http://dx.doi.org/10.1006/ mcpr.1996.0038. PMid:8865177

Lehmann T, Graham DH, Dahl E, Sreekumar C, Launer F, Corn JL, et al. Transmission dynamics of Toxoplasma gondii on a pig farm. 
Infect Genet Evol2003; 3(2): 135-141. http://dx.doi.org/10.1016/S15671348(03)00067-4. PMid:12809808

Montoya JG, Liesenfeld O. Toxoplasmosis. Lancet 2004; 363(9425): 1965-1976. http://dx.doi.org/10.1016/S0140-6736(04)16412-X. PMid: 15194258

Ogrzewalska M, Uezu A, Labruna MB. Ticks (Acari: Ixodidae) infesting wild birds in the Atlantic Forest in northeastern Brazil, with notes on rickettsial infection in ticks. Parasitol Res 2011; 108(3): 665-670. http:// dx.doi.org/10.1007/s00436-010-2111-8. PMid:20953629

Paglia AP, Fonseca GA, Rylands BR, Herrmann G, Aguiar LMS, Chiarello AG, et al. Annotated cheklist of Brazilian mammals. 2nd ed. Arlington: Conservation International; 2012. no. 6. Occasional Papers in Conservation Biology.

Pena HFJ, Soares RM, Amaku M, Dubey JP, Gennari SM. Toxoplasma gondii infection in cats from São Paulo state, Brazil: seroprevalence, oocyst shedding, isolation in mice, and biologic and molecular characterization. Res Vet Sci 2006; 81(1): 58-67. http://dx.doi. org/10.1016/j.rvsc.2005.09.007. PMid:16289158

Ramalho AMZ, Pimenta HCD. Valoração econômica do dano ambiental ocasionado pela extraçáo ilegal da orquídea Cattleya granulosa no Parque Natural Dom Nivaldo Monte, Natal/RN. Holos 2010; 1(26): 62-82.

Remington JS, McLeod R, Thulliez P, Desmonts G. Toxoplasmosis. In: Remington JS, Klein JO, Wilson CB, Baker CJ, editors. Infectious diseases of the fetus and newborn infant. 6th ed. Philadelphia: WB Saunders; 2006. p. 947-1091. http://dx.doi.org/10.1016/B0-72-160537-0/50033-5.

Salgado AC, Sales LC, Andrade DAP, Rodrigues LA. Percepção dos funcionários residentes no Parque Estadual Alberto Löfgren sobre o conceito de posse responsável. IF Série Registros 2007; 31: 107-111.

Sangster CR, Gordon AN, Hayes D. Systemic toxoplasmosis in captive flying-foxes. Aust Vet J2012; 90(4): 140-142. http://dx.doi.org/10.1111/ j.1751-0813.2011.00868.x. PMid:22443329

Schatzberg SJ, Haley NJ, Barr SC, deLahunta A, Olby N, Munana $\mathrm{K}$, et al. Use of a multiplex polymerase chain reaction assay in the antemortem diagnosis of toxoplasmosis and neosporosis in the central nervous system of cats and dogs. Am J Vet Res 2003; 64(12): 1507-1513. http://dx.doi.org/10.2460/ajvr.2003.64.1507. PMid:14672429

Silva AV, Silva RC, Zamprogna TO, Lucas TM. Toxoplasma gondii em Suínos com ênfase na contribuição brasileira. Scient Med 2010; 20(1): 120-130.

Silva JCR, Gennari SM, Ragozo AMA, Amajones VR, Magnabosco C, Yai LEO, et al. Prevalence of Toxoplasma gondii antibodies in sera of domestic cats from Guarulhos and São Paulo, Brazil. J Parasitol 2002; 88(2): 419-420. PMid:12054029.

Silva JCR, Ogassawara S, Adania CH, Ferreira F, Gennari SM, Dubey JP, et al. Seroprevalence of Toxoplasma gondii in captive neotropical felids from Brazil. Vet Parasitol 2001; 102(3): 217-224. http://dx.doi. org/10.1016/S0304-4017(01)00523-4. PMid:11777601

Siqueira DB, Aléssio FM, Mauffrey JF, Marvulo MF, Ribeiro VO, Oliveira RL, et al. Seroprevalence of Toxoplasma gondii in wild marsupials and rodents from the Atlantic forest of Pernambuco state, northeastern region, Brazil. J Parasitol 2013; 99(6): 1140-1143. http://dx.doi.org/10.1645/ GE-2855.1. PMid:23829204

Terra MAB, Bello AR, Bastos OM, Amendoeira MRR, Coelho JMCO, Ferreira LF, et al. Detection of Toxoplasma gondii DNA by polymerase chain reaction in experimentally desiccated tissues. Mem Inst Oswaldo Cruz 2004; 99(2): 185-188. http://dx.doi.org/10.1590/S007402762004000200012. PMid:15250473

Vitaliano SN, Mineo TWP, André MR, Machado RZ, Mineo JR, Werther K. Experimental infection of crested caracara (Caracara plancus) with Toxoplasma gondii simulating natural conditions. Vet Parasitol 2010 172(1-2): 71-75. http://dx.doi.org/10.1016/j.vetpar.2010.04.010. PMid:20451327

Yai LEO, Cañon-Franco WA, Geraldi VC, Summa MEL, Camargo MCGO, Dubey JP, et al. Seroprevalence of Neospora caninum and Toxoplasma gondii antibodies in the South American opossum (Didelphis marsupialis) from the city of São Paulo, Brazil. J Parasitol 2003; 89(4): 870-871. http://dx.doi.org/10.1645/GE-83R. PMid:14533710 